\title{
Religious Difference and Democratic Pluralism: Some Recent Debates and Frameworks
}

\author{
CHARLES HIRSCHKIND \\ University of California
}

\begin{abstract}
While until quite recently debates in political philosophy on questions of pluralism, tolerance, and liberal governance foregrounded notions of culture and cultural difference, today it is religion that increasingly provides the historical and conceptual resources for the contemporary reassessment of the pragmatic and philosophical conditions for pluralist democracy. Drawing on a few recent writings in the field of political theology, this paper explores some of the analytical directions that this repositioning of religion within contemporary narratives of modernity has opened up within political philosophy. As I seek to demonstrate, the domain of political theology has become the problem space, where the tensions and contradictions between a simultaneous insistence on Europe's secular identity and its Christian one are being elaborated. Through a certain double movement, secularism and Christianity have become productively fused within the writings I address, in a way that repeats the story of European exceptionality while inscribing the essential otherness of the Muslim populations within its borders. In the second part of the paper, I want to contrast these reflections from political philosophy with debates in postcolonial Egypt around issues of religion and the possibility of democratic pluralism.
\end{abstract}

Keywords: religious pluralism, political theology, secularism, Islam, Europe, Egypt

Among many scholars today, there is a widely shared feeling that our conventional frameworks for understanding religion are inadequate to the challenges that religious movements pose to secular-liberal modes of governance. The increasing fear and anxiety within Europe regarding the presence of Muslim immigrants within its bounds, the burgeoning political power of evangelical Christians in the US, and, more generally, the increasing salience of politicized religious movements around the globe, most notably in the Middle East, have all contributed, if in different ways, to a perception that religion merits greater scholarly attention than it has received. One of the common responses to the 'return of the religious', of course, has been 
a forceful reassertion of secular principles, understood as a prophylactic to the dangers of religious irrationality and violence. For many, however, the challenges posed by contemporary religious movements have prompted a more careful re-examination of the relation of religious traditions to the concepts and practices of secular-liberal democracies. ${ }^{1}$ It is notable that, until quite recently, debates in political philosophy on questions of pluralism, tolerance, and liberal governance foregrounded notions of culture and cultural difference, rarely addressing religion as anything but a particular variant of these. In the work of Rawls (2005), Kymlicka (1991), and Dworkin (1986), for example, the demands of religious adherence never extend beyond the political limits authorized by the culture concept. Today, in stark contrast, it is religion that increasingly provides the historical and conceptual resources for the contemporary reassessment of the pragmatic and philosophical conditions for pluralist democracy.

In this article, I want to begin by exploring some of the analytical directions that this repositioning of religion within the story of modernity has opened up within political philosophy. While the writings I examine constitute only a small sample of this wide and diverse field of inquiry, I draw on them because it seems to me they exemplify a broader trend within contemporary political thought. Specifically, I want to ask: what displacements or fractures occur within the story of European modernity once religion is no longer identified as an obstacle that is overcome by modernity, but rather as itself a constitutive element of a modern political order? What challenges does an understanding of modernity as in some sense a religious - and specifically Christian - achievement pose for secular-liberal models of religious pluralism, particularly in the context of European debates about the presence of Muslims in Europe? If, as many have argued, 'culture' and the discourse of multiculturalism have tended to objectify difference in ways that are neutral in relation to the imperatives of liberal governance, what does the concept of religion open up to political reflection?

In the second part of the article, I want to contrast these reflections from political philosophy with debates in postcolonial Egypt around issues of religion and the possibility of democratic pluralism. One of the most frequent critiques made of Egypt's Islamic Revival movement has been that its very attempt to harness politics to a religious tradition necessarily imperils the pluralist framework essential to a multireligious and multiethnic society. I want to question this claim through a brief discussion of some of the divergent discourses on the status of religious minorities in Egypt, discourses that articulate both with institutions of democracy and traditions of Islam.

\footnotetext{
${ }^{1}$ See for example Asad (2003); Masuzawa (2005); Smith (2004); Taylor (2007).
} 


\section{Christianity and Democracy}

One of the central questions posed by contemporary European scholarship concerning political theology today runs something like this: in what way are we (Europeans) Christian today, and what are the implications of this identity for our political life? It is interesting to note that the renewed concern for the theological political in Europe occurs precisely when preoccupations about Islam within its borders have led many Europeans to argue that their Christian heritage is essential to the civilizational identity of Europe. ${ }^{2}$ How might we view current inquiries into political theology in relation to such anxieties within Europe? How might these anxieties have shaped the kinds of questions that are being pursued through this reengagement with the religious? One of my arguments here, to get ahead of myself a little, is that the domain of political theology has become the problem space, wherein the tensions and contradictions between a simultaneous insistence on Europe's secular identity and its Christian one are being elaborated. Through a certain double movement secularism and Christianity have become productively fused, in a way that repeats the story of European exceptionality while inscribing the essential otherness of the Muslim populations within its borders.

One writer who has addressed these issues is Marcel Gauchet. Gauchet has written a sweeping historical account that links the emergence of modernity to a set of logical developments within Christianity itself (Gauchet 1999). While I clearly cannot do justice to Gauchet's complex work in this short article, I will restrict myself to a few observations. In an argument that echoes both Durkheim and Feuerbach, Gauchet posits that religion, as a historical phenomenon, is a way of 'institutionalizing humans against themselves', by attributing humankind's own power to transform and organize the world to otherworldly forces. The political history of religion, in short, is one of human disempowerment. It is Christianity, according to Gauchet, that introduces a decisive rupture in this history, and sets in play the dynamics which eventually culminate in the autonomous subject of modern democratic political life. The dynamic of transcendence introduced by Christianity for the first time allows for the thematization of earthly power. The radical divide between the divine and human opens up a space for purely human action, inaugurating a shift from the heteronomous culture of religion to politics, and the concomitant rise of the modern notion of

\footnotetext{
${ }^{2}$ A number of the signatory states to the Constitution of the European Union (including Italy and Poland) pushed to have a statement recognizing the 'Christian roots of Europe' included in the document. Following extensive debate on the issue, however, the phrase was dropped from the final draft of the Constitution.
} 
sovereignty. In addition, the Christian emphasis on conscience eventually encourages the questioning of religious authority through acts of individual interpretation and evaluation, thereby furthering the drive toward greater autonomy. Once set in motion, this teleological process leads to Christianity's own self-overcoming, a process that culminates in the creation of a modern secular political order and the relegation of religious belief to private experience.

Gauchet's account of the processes of individualization and differentiation leading to modernity is a familiar one, with the difference that what others have tended to ascribe to developments in the sixteenth century, Gauchet finds already present, in germinal form, at Christianity's origin. What interests me here, however, is not the historical or sociological adequacy of the account, but the way it naturalizes one particular form of religious expression as the end point of religion's logical development. Indeed, it turns out that the modern concept of religion as private belief conforms to religion in its essence. For Gauchet, as he argues in his 'Introduction', religion in its essence, outside its historical embodiment in institutional forms, is essentially a matter of subjective experience, an anthropological universal that even when its organized forms finally die out, as they must, will continue to play a role in the modern world. In a post-theistic secular society, religion finally comes to coincide with its essential nature.

Gauchet goes much further than simply recognizing that Christian concepts or practices are historically entwined with our modern political institutions, as asserted for example by Carl Schmitt (2005/1922). A certain post-Reformation understanding of Christianity is valorized as true religion in its undistorted form, while all other religious traditions and forms of religiosity are recognized as incompatible with modernity, lacking the doctrinal resources that would enable them to accede to the modern. ${ }^{3}$ The incorporation of what had been modernity's other - religion - into its very fabric does not decenter the conceptual edifice of European modernity in any way that might allow a reconsideration of Europe's religious minorities, but on the contrary redoubles it, deepening the fundamental otherness of those who cannot inhabit its Christian genealogy. Both secular politics and private belief emerge as the inheritors of the arc of religion returning to itself. Muslims whose religious practices make claims on public life are not merely a threat to the necessarily secular foundation of a pluralist democratic

\footnotetext{
${ }^{3}$ Not surprisingly, Gauchet's few comments on Islam rehearse some of the standard criticisms found in Western anti-Islamic polemics: that the Qur'an restricts human interpretive agency while the Bible promotes it $(1999,80)$; that Islam encourages conquest and expansion through force of arms, while Christianity places value on activities 'turning people away from confrontation' (1999, 93).
} 
society; their claims also distort religion's essential nature. For as Gauchet notes, 'evidence suggests that this inner sense of otherness [that is, religion] is socially neutral' $(1999,103)$.

One result of such an account, of course, is to make Christianity consubstantial with Europe. As Jean Luc Nancy notes, in the context of expressing his 'complete agreement' with Gauchet's thesis, 'Christianity is inseparable form the West [...] Although the de-Christianization of the West is far from being a hollow phrase, the more it takes hold and the more visible it becomes [...] the more we are bound within the very fabric of Christianity.' (Nancy 2001, 115.) The fact that Christianity first emerged in what is now the Middle East, or that the majority of its adherents live outside of the West would suggest its relation to the West is far more contingent than what is claimed here. How do we understand this recentering of the European subject in relation to the contemporary struggles for inclusion by Muslims and other religious minorities in Europe?

Let me turn to another prominent thinker who has recently turned to religion in his writings, Slavoj Zizek. Zizek finds in the Christian tradition a resource for thinking critically about the shortcomings of liberalism, in particular liberalism's anemic notion of free choice (Zizek 2001). His engagement with Christianity is therefore primarily conceptual, and differs considerably from Gauchet's far more historical and sociological project. Zizek's primary target is a common one: the psychological subject presupposed in the liberal idea of choice. Liberalism, he argues, following Marx among others, is blind to the extent the kind of choices it authorizes are already structured by 'closed, fully contextualized' situations, situations in which possible choices are already determined prior to any conscious act by a subject. Against the formal freedoms of liberalism, Zizek seeks to recuperate from Christianity an idea of actual freedom as embodied in the concept of radical choice, an idea that finds one expression in Kierkegaard's notion of 'the suspension of the ethical'. As Zizek asserts, in a phrase that bears considerable resemblance to Gauchet's position: 'Christianity is, from its very inception, the religion of modernity: what the Christian notion of the suspension of the law aims at is precisely this gap between the domain of moral norms and faith' (Zizek 2001, 150). It is particularly to modern Christian theology that Zizek turns in order to make his case: the limits of divine omnipotence disclosed in Christ's crucifixion offers the space for 'undoing' one's coordinates of existence. It is within the discourses of religion, in other words, that one finds the space for a primordial act of reversing the law by suspending it. Actual freedom, in this light, can therefore be envisioned by 
way of self-willed transformation, made possible in the abandonment of a unitary, material and freely choosing self.

Zizek's engagement with Christianity is far more complex that I can do justice to here. One might expect, however, that Zizek's emphasis on the limits of the divine, or the symbolic order, as figured in Christ's necessarily imperfect humanity, might open up the possibility of thinking about contemporary problems of religious difference outside the received frameworks of secular-liberalism. His reaction, therefore, to the worldwide protests that took place in the aftermath of the publication and re-publication of the Danish cartoons depicting the Prophet Muhammad as a terrorist is surprising but also instructive. In a New York Times editorial on these events, Zizek imputes amoral motives to the protesters, whom he condemns as 'fundamentalists', while asserting that the liberal journalists who republished the cartoons did so out of a moral commitment to free expression (Zizek 2006). What makes his commentary particularly relevant in this context is his assimilation of Christianity to atheism, a move that mirrors the sort of double gesture I have noted above in regard to Gauchet's work. He writes: 'a properly Christian ethical stance survives mostly in atheism. Fundamentalists do what they perceive as good deeds in order to fulfill God's will and to earn salvation; atheists do them simply because it is the right thing to do' (Zizek 2006). It is odd that a self-declared atheist invokes a Christian moral tradition as an authority by which to judge and understand Muslims protests over the cartoon depictions. The Enlightenment critique of religion is repeated here, a repetition that secures the moral supremacy of liberal (and Christian!) Europe while condemning the non-Christians within it whom he accuses, echoing Kant, of failing to attain adulthood. In a telling shift, the enemy of the Enlightenment is no longer 'religion', now understood as one of Europe's greatest moral assets, but fundamentalism: namely, those traditions of religious practice that fail to accede to the universality of post-theistic Christianity and therefore sit uncomfortably with the liberal sensibilities of modern Europeans.

The philosophical redemption of religion within the modern works in these writings by defining a new abject other, fundamentalism, with Islam as its paradigmatic instance. ${ }^{4}$ Fundamentalism marks both a political and analytical boundary, one which we need not and indeed must not traverse. Its flattening light illuminates only those surfaces upon which liberal anxieties can fix themselves but leaves in darkness all of the surrounding density and complexity. The judgment encoded in the appellation 'fundamental-

\footnotetext{
${ }^{4}$ Different versions of this argument can also be found in texts of Caputo (2001) and Vattimo (1999).
} 
ism' is singular: contemporary Islamic activist movements, while worthy of sociological and political attention, are essentially uninteresting and contribute very little to our understanding of human value and creativity, let alone our capacities of moral and political imagination.

My aim so far has been to point to some of the directions taken by authors concerned with the theological political, and to suggest why this work should be seen in light of the contemporary consolidation of a European civilizational identity rather than the opening up of a space to think outside it. Let me reiterate that I am not claiming by any means that all contemporary scholarship on political theology necessarily shares the judgments and positions I have identified in the writings of Gauchet and Zizek. My attempt here is rather to delineate what I consider to be one of the more influential styles of inquiry in this field, and to situate it in relation to the problem of religious pluralism. The lines of investigation I have explored in many ways echo the nineteenth-century idea of universal religion, according to which all religions share a fundamental essence, one that nonetheless finds its most perfect historical embodiment in Christianity (see Masuzawa 2005). Accounts of this sort introduce religion into the conceptual vocabulary of modern political life in a way that simultaneously naturalizes one particular religious tradition and secures the civilizational boundaries of modern Europe. Instead of inquiring into the historical development of the profoundly entwined categories of secularity and religion, the analysis effects a philosophical reduction of one to the other. How does this particular Christianization of secular modernity impact on the status of Muslims in Europe? The 'openness to the other' celebrated by these authors as religion's value to modernity depends upon a recognizably secular-liberal sensibility whereby those others worthy of openness can be distinguished from those who are not. Yet how can one recognize what kinds of openness the so-called 'fundamentalists' might either be capable of or merit in return, unless one goes beyond a simple dismissal?

\section{Secular Discipline}

This raises another important issue. As Talal Asad has argued, secularism has not entailed the banishment of religion from modern life, but its reconstruction as both a private space of personal experience and a set of propositions to which the individual believer gives subjective assent (Asad 2003). This project of reconstruction is carried out through practices of social and individual discipline by means of which the attitudes, affects, and sensibilities of a modern religious subject are honed and refined. In the works I have 
discussed here, a certain form of Christianity is abstracted and universalized in a way that completely obscures the embodied and disciplinary character of the subject of secular tolerance. It is only in the context of such an abstraction, one devoid of any sociological entailments, that Gauchet can confidently assert that religion, in its essence, is socially neutral.

It is in postcolonial contexts such as Egypt, where the project of producing such a modern religious subject is still underway, often through authoritarian means, that the operation of secular discipline can be easily observed, and the parochial character of such a subject highlighted. I now want to turn to the Egyptian context, both to examine the contemporary statist project of constructing a modern religious subject, but also to note how the question of democratic pluralism is being imagined differently, outside the framework of a modern Christian inheritance.

Against the backdrop of over a hundred years of colonial and postcolonial rule in Egypt, during which religious authority has increasingly come to be regulated by state institutions, there has emerged a strong resistance movement, in the form of the Islamic Revival. This movement seeks to restore orthodox religious practices and ethical forms of belonging that have been corroded by statist practices of religious reform. While some of the oppositional movement has taken a militant form, most of it is geared toward transforming the ethical moorings of ordinary Egyptians through a vast re-education of their life styles, habits, and sensibilities (see Hirschkind 2006; Mahmood 2005). The Egyptian state, for its part, is anxious about the loyalties and commitments of the religious subject being forged within the Islamic Revival movement, and in response has sought to construct a domain of private life to which they might be confined.

It is notable that the same distinction between 'authentic' religion and fundamentalism, so key to the works within political philosophy that I address above, has also been instrumental to the Egyptian state's contemporary effort to refashion the religious sensibilities of its citizens and quell religious opposition in the country. In the state's current narrative of national progress - of Egypt's historic trajectory from backwardness, ignorance, and poverty to development, enlightenment, and wealth - the 'fundamentalist personality' and the traditional Islamic institutions which purportedly give rise to it are seen as a remnant from an earlier historical period, one whose anachronistic presence threatens to destroy the social order. Thus the continued use of techniques of memorization and recitation in schools is often singled out as a key contributor to 'the spread of extremist thinking among young people, who are ill-equipped to resist brainwashing' (Al-Ahram 1993). 
The Islamic traditions of training and scholarly preparation, as elaborated in this modernist critique, produce ignorant and socially dangerous individuals whose behavior reflects the prevalence of 'instinct' over the values of culture and civilization.

As in other postcolonial contexts, the task of constructing a modern Muslim subject has been carried out through a wide variety of legal and administrative means. This project today involves the continuous elaboration of new initiatives and measures designed to counter the threat of fundamentalism as well as a constant flow of public discourse about how this is to be achieved. The following statement from the Minister of Culture is characteristic of such advice:

We should restore mosques once again to their proper function as places of worship, and provide young people with plenty of other accessible leisure activities, so that they can live like normal young people, studying or working in the morning, going to their place of worship to pray, and then in their leisure time going to the cinema, theatre or library, or taking part in their favorite sport. (Al-Ahram 1993.)

For 'normal young people', Islam - as individual spiritual practice - should stand as a brief interlude between the two primary modes of existence around which the times and spaces of daily life are arranged: work and leisure. It is not surprising, in this regard, that the notion of 'cultural security' has emerged in public discussion as a pivotal term for the task of countering the so-called fundamentalist tendency of the Islamic Revival. Indeed, it is precisely this disjuncture between the kind of public subject fashioned within the Islamic Revival movement and one who will perform the role of national citizen inhabiting a private domain of unconditional immunity that has made 'culture' into a site of considerable struggle.

For proponents of the Islamic Revival, the danger of Western cultural forms and popular media entertainment lies in the fact that they engender emotions and character attributes incompatible with those that in their view enable one to live as a pious Muslim (Hirschkind 2006). As a preacher I studied with in Cairo told me, echoing a widely held opinion, ' $[t]$ he enemies of Islam use art [fann], literature [adab], culture [thaqafa], and fashion [muda] to attack Islam', a comment explicitly acknowledging the Western and secular genealogy of these categories of discourse and practice. Much of the criticism found in popular cassette sermons and other literature from the Revival 
movement is directed at media entertainment, film stars, popular singers, and television serials. In a sermon entitled 'The Illicit Desires' for example, one of Egypt's most popular Revival preachers, Muhammad Hassan, takes issue with a religious scholar who has recently stated that it is permissible to listen to popular music. To emphasize his point, Hassan mentions a music tape that was quite popular in Egypt at the time, noting:

[w]e all know that cursed tape 'Luna'. It has sold more than eighty million copies, and there is nowhere you can go to escape from it. Young people listen and sing the words. It puts these words full of illicit desires into the mouths of the young people until they go out and commit sins.

What is at stake here is not simply a case of political criticisms being deflected onto the safer realm of culture. According to many Revival participants in Egypt, most forms of popular media entertainment engage and direct the senses toward moral dispositions, states of the soul, that are incompatible with the virtues upon which an Islamic society rests. In response, proponents of the Revival have sought to reshape the sensory fabric of everyday life, through the creation of aesthetic forms, media practices, soundscapes, and styles of sociability that nourish and sustain the affects and sensibilities understood to facilitate ethical conduct.

How does a recognition of the disciplinary conditions and embodied character of religious subjects - whether post-secular Christian or Revivalist Islamic - bear upon the question of religious tolerance and democratic pluralism? It suggests, among other things, that the limits of tolerance are intimately linked to the limits of the body as an ensemble of culturally honed dispositions and modes of expression. Understood as an embodied sensibility cultivated by those who inhabit secular societies, the practice of secular toleration will necessarily stand in a very different relation to other religious traditions than to it does to the Protestant Christian traditions of modern Europe wherein it emerged. ${ }^{5}$ One need only remember that for many Christian missionaries the acceptance of what was called the White Man's Burden was an act of Christian generosity, to recognize that an ethic of generosity, or tolerance, or 'openness to others', will never be universalizable, and may well be destructive of the forms of life to which it is extended. It is the fact that secular ideology has a built-in structural blindness to this point that makes possible a claim like Zizek's, that the re-publication of im-

\footnotetext{
${ }^{5}$ An excellent exploration of the genealogy and limits of the liberal notion of tolerance is found in Wendy Brown's fine book, Regulation Aversion: Tolerance in the Age of Identity and Empire (2006).
} 
ages that many Muslims found injurious is an exemplary act of tolerance, and indeed, that the publishers who did so are actually the closest allies of Muslim immigrants in Europe. ${ }^{6}$

\section{Egyptian Debates}

As I mentioned above, the state's attempt to frame the question of religious pluralism in Egypt in secular-nationalist terms is contested by various protagonists of the Islamic Revival movement, who argue in response that the traditions of Islam provide the ethical and political resources for achieving a just resolution of the problem of religious minorities in a modern nation state. What makes these debates interesting in relation to my discussion of political philosophy above, I want to suggest, is the way they raise questions about religion in relation to democratic pluralism, questions generally unaddressed within contemporary discussions of religious minorities. Before I turn to these debates, however, it is worth remembering that the problem of accommodating religious minorities within the framework of the nation is owing to the contradictory character of the nation form itself, as a space defined in both universalist and particularist terms. On the one hand, the modern nation form is founded upon a vocabulary of universal rights, in respect to which distinctions of culture, class, ethnicity, or religion are disregarded. Within this framework, public discourse is not supposed to be organized on the basis of religious difference. The juridical relegation of organized religion to the sphere of private life helps secure this norm. On the other hand, the nation also incorporates a notion of cultural identity - the values, history, and language through which the unity and particularity of 'the people' as a nation is established. 'Religion' (however we might understand the term) is deeply entwined with the historical sources from which the idea of a unified national culture is constructed. Indeed, we have seen one particular articulation of this project in the works discussed above. Insomuch as a national polity is representative of 'majoritarian' values (be they religious or cultural), it stands in a necessary relation of tension with the nation's 'minority' traditions. The conflict between universalist and particularist currents of national political life, therefore, cannot be attributed to the rise of religious movements alone precisely because this conflict is integral to the project of secular nationalism itself. The explicitly secular-nationalist project of modern India, for example, has from its inception depended on the deployment of a distinctly Hindu symbolism (see Chatterjee 1993; Hansen

${ }^{6}$ Some of the ethical and legal dimensions of the cartoon controversy are usefully analyzed in Mahmood (2008) and Mamdani (2006). 
1999). In Egypt as well, the national project has from its commencement tended to disfavor and marginalize Coptic Christians in various ways.

The Islamic Revival has generated a number of diverse stances and arguments on the issue of Egypt's Coptic Christian minority. On the one hand, a number of prominent religious thinkers have sought to develop concepts and models based in Islamic juridical and doctrinal resources and capable of responding to contemporary problems of political governance on the issue of religious minorities (al-Bishri 2005; Huwaidi 1985; al-Qaradawi 1997). These engagements with Islam textual traditions often involve a rejection of regnant interpretations of the classical Islamic concept of wilaya, a notion conventionally interpreted to mean that non-Muslims should not be in a position of rule over Muslims (see Baker 2003, 178-98). Indeed, today a number of the leaders of Islamist political associations now support the view that qualified Copts should be able to hold the highest of offices within a Muslim majority political order, as long as they uphold the Islamic principles on which that order is based. Thus a number of small political parties, some of them offshoots of the Muslim Brotherhood (e.g., the Wasat Party, the Union for Freedom Party), have included Copts among their leadership and have sought to encourage Coptic participation (al-Ahram 2007). The Brotherhood itself has also reached out to Copts in recent years, and has supported Brotherhood-allied Coptic political candidates now in a number of elections. Another recently founded opposition movement, the Kifaya Movement, was initially led by George Issac, a Copt, though now has Abd al-Wahhab al-Massiri - a public intellectual with Islamist leanings - as its acting director. What these examples highlight are not only convergences between Coptic and Islamist political currents, but also a growing rapprochement between secular-leftist and Islamism thinkers and activists that is reshaping the political field in Egypt today (see El-Hamalawy 2007).

Founded in 1994 by Abu 'Ala Madi and a group of activists and writers that included both Muslim Brothers and Copts, the Wasat party is but one of a number of political experiments attempting to think about the problem of minority participation in light of Egypt's historical embeddedness within the traditions of Islam. The party's leaders insist that the shari'a must be interpreted in the light of contemporary conditions, especially in relation to the necessity of establishing a legal and political system that grants the same rights and duties to all of its citizens, regardless of religious affiliation. Islam, in the view put forward by the party, is not simply a set of traditions bearing on the lives of Muslims, but part of the historical fabric that has shaped life in Egypt for both Muslims and Christians - what party docu- 
ments refer to as a 'concept of Islamic civilization'. One of the founding members, Rafiq Habib, a Protestant Christian, puts the argument as follows: 'we are trying to say that our Islamic culture, we are not speaking about religion, is what brings us together. It is a very modern notion.' (Cited in Stacher 2002.) Within the formula articulated in the party's founding documents, Muslims and Christians are viewed as having been co-partners in the creation of a shared civilization and therefore equally eligible to participate in its continued governance. Notably, leaders of the Coptic Christian Church in Egypt, in attempting to articulate their relation to the Muslim majority, have also frequently made reference to the Church's historical location within a broader Islamic civilizational matrix. How this notion of a broader Islamic civilization encompassing Egypt's minorities will shape an approach to contemporary legal and political challenges remains to be seen. What I want to call attention to here, however, is precisely the fact that such efforts have been taken up with ever more frequency and seriousness during the last decade in Egypt.

The Muslim Brotherhood has also gradually shifted its official positions on the issue of non-Muslims in Egypt, though not as far as some of the smaller Islam-centered parties that have broken away from the Brotherhood. Thus, in the Brotherhood's latest political manifesto, a preliminary draft of which was published in January of this year (2008), the group maintains its position that while Copts may occupy high positions within the government, the office of the presidency should be reserved for a Muslim. That said, following the early release of the draft, a number of junior members of the group voiced strong objections to the imposition of this restriction on Coptic participation (see Houdaiby 2008). Indeed, today there is a generational fault line that is dividing the Brotherhood precisely around issues such as this one, with many of the younger members calling for a strengthening of ties both with Copts as well as secular-leftist opponents of the government. ${ }^{7}$ As it stands, a final draft of the political manifesto has been held up in order to allow further discussion and debate among members on some of these issues.

This brief review of some of the currents shaping Egyptian political discourse today around the issue of religious minorities should not give the impression that the problem of Muslim-Christian tensions in the country has been solved. On the contrary: anti-Coptic attitudes continue to find expression within diverse social and political arenas, including both the Muslim Brotherhood and the ruling National Democratic Party. Moreover, acts of

\footnotetext{
7 Hossam El-Hamalawy (2007) gives a first hand account of the increasing cooperation between Brotherhood activists and leftists on Egyptian campuses in recent years.
} 
violence against Copts have occurred with considerable frequency over the last decades, especially in the smaller towns of Upper Egypt, though also in both Cairo and Alexandria. My aim here, therefore, is not to point to a lack of inter-religious tension in Egypt, but to highlight the important role being played by Islamist thinkers and political movements in attempting to formulate a response to this problem. These attempts include rethinking certain foundational tenets of the Islamic shari'a - such as the category dhimmi (or 'protected non-Muslim minority'), or the notion of wilaya mentioned above - in the light of the historical entwinement of Muslim and Christian communities within Egyptian history. Such efforts, moreover, have enabled an increasing (though admittedly still small) number of Copts to work within the framework of Islamist political associations, like the Brotherhood, in order to build a political order more responsive to the needs of non-Muslim groups within Egypt. ${ }^{8}$ These innovative efforts, encompassing histories and concepts outside the discursive boundaries defined by secularism and secularity, should be of great interest to anyone concerned with contemporary problems of religious pluralism.

Bibliography

Al-Ahram Weekly, February 25-March 3, 1993.

Al-Ahram Weekly, August 16-22, 2007.

Asad, Talal

2003 Formations of the Secular: Christianity, Islam, Modernity. Stanford: Stanford University Press.

\section{Baker, Raymond}

2003 Islam without Fear: Egypt and the New Islamists. Cambridge MA: Harvard University Press.

\section{Al-Bishri, Tariq}

2005 al-Jama'a al-wataniyya: al-'uzla wa al-indimaj. Cairo: Kitab al-Hilal.

\footnotetext{
8 In the elections planned for April of 2008, the Brotherhood indicated that it would support fifteen Coptic candidates. As it turned out, almost all Brotherhood-supported candidates were excluded by the Egyptian government from participating in the election, close to 10,000 candidates in all.
} 


\section{Brown, Wendy}

2006 Regulation Aversion: Tolerance in the Age of Identity and Empire. Princeton: Princeton University Press.

\section{Caputo, John}

2001 On Religion. New York: Routledge.

\section{Chatterjee, Partha}

1993 The Nation and Its Fragments: Colonial and Postcolonial Histories. Princeton: Princeton University Press.

\section{Dworkin, Ronald}

1986 Law's Empire. Boston: Belknap Press of Harvard University Press.

\section{Gauchet, Marcel}

1999 The Disenchantment of the World: A Political History of Religion. Princeton: Princeton University Press.

\section{El-Hamalawy, Hossam}

2007 Comrades and Brothers. - MERIP 242. http://www.merip.org/mer/ mer242/mer242.html, accessed on January 10, 2008.

\section{Hansen, Thomas Blom}

1999 The Saffron Wave: Democracy and Hindu Nationalism in Modern India. Princeton: Princeton University Press.

\section{Hirschkind, Charles}

2006 The Ethical Soundscape: Cassette Sermons and Islamic Counterpublics. New York: Columbia University Press.

\section{Houdaiby, Ibrahim L.}

2008 The Brotherhood Opens Up. - Comment is Free. http://commentisfree. guardian.co.uk/ibrahim_el_houdaiby/2008/01/the_brotherhood_ opens_up.html.

\section{Huwaidi, Fahmi}

1985 Muwatinun la Dhimmiyyun. Cairo: Dar al-Shuruk.

\section{Kymlicka, Will}

1991 Liberalism, Community, and Culture. New York: Oxford University Press.

\section{Mahmood, Saba}

2005 Politics of Piety: The Islamic Revival and the Feminist Subject. Princeton: Princeton University Press.

2008 Religious Reason and Secular Affect: An Incommensurable Divide. - Critical Inquiry (forthcoming). 


\section{Mamdani, Mahmood}

2006 The Political Uses of Free Speech. - Daily Times, Friday, February 16, 1.

Al-Masri al-Yom, Wednesday, March 12, 2008.

\section{Masuzawa, Tomoko}

2005 The Invention of World Religions. Or, How European Universalism was Preserved in the Name of Pluralism. Chicago: Chicago University Press.

Nancy, Jean-Luc

2001 The Deconstruction of Christianity - Hent de Vries and Samuel Weber (eds), 111-122, Religion and Media. Stanford: Stanford University Press.

\section{Al-Qaradawi, Yusuf}

1997 Ghayr al-Muslimin fi el-Mujtama`al-Islami. Cairo: Wahbah Press.

\section{Rawls, John}

2005 Political Liberalism. New York: Columbia University Press.

\section{Schmitt, Carl}

2005 (1922) Political Theology: Four Chapters on the Concept of Sovereignty. Chicago: University of Chicago Press.

\section{Smith, Jonathan Z.}

2004 Relating Religion: Essays in the Study of Religion. Chicago: University of Chicago Press.

\section{Stacher, Jonathan}

2002 Post-Islamist Rumblings in Egypt: the Emergence of the Wasat Party. - The Middle East Journal 56 (3), 415-20.

\section{Taylor, Charles $A$.}

2007 A Secular Age. Cambridge MA: The Belknap Press.

\section{Vattimo, Gianni}

1999 Belief. Stanford: Stanford University Press.

\section{Zizek, Slavoj}

2001 On Belief. New York: Routledge.

2006 Defenders of the Faith. - New York Times, Op-Ed, March 12, 2006. http://query.nytimes.com/gst/fullpage.html?res=9C07E3D71331F93 1A25750C0A9609C8B63\&sec=\&spon=\&pagewanted=all. 